\title{
Virus in the Urine of Healthy People and Patients with Infectious Diseases
}

\author{
Sunho Park, Eui Tae Kim', Jung-Sik Huh ${ }^{2}$ \\ Department of Physiology, Ajou University School of Medicine, Suwon, ${ }^{I}$ Department of Microbiology and Immunology, Jeju National University \\ College of Medicine, ${ }^{2}$ Department of Urology, Jeju National University Hospital, Jeju National University College of Medicine, Jeju, Korea
}

There has been a sustained effort to overcome the multiple infectious diseases that confront humankind. Urinary tract infections (UTIS) are most commonly caused by bacterial pathogens, primarily Escherichia coli. However, UTIs by viral pathogens have not been significantly reported. The human urinary tract, both in the healthy and diseased states, is home to many viruses despite the traditional belief that urine is sterile in healthy individuals. The most common viral pathogens found in the urinary tract are the human polyomavirus (BK virus), adenovirus, cytomegalovirus, and herpes simplex virus type- 1 and type-2. Research should continue to investigate whether these viruses cause clinical infections or are mere colonizers of the urinary tract.

Keywords: Urinary tract infections; Viruses; Bacteria

Copyright (c) 2021, Korean Association of Urogenital Tract Infection and Inflammation. All rights reserved. (1) This is an open access article distributed under the terms of the Creative Commons Attribution (c) Non-Commercial License (http://creativecommons.org/licenses/by-nc/4.0) which permits unrestricted non-commercial use, distribution, and reproduction in any medium, provided the original work is properly cited.
Received: 14 April, 2021

Revised: 9 May, 2021

Accepted: 20 August, 2021

\section{INTRODUCTION}

There has been a sustained effort to overcome the multiple infectious diseases that confront humankind through newer antibiotics. Antibiotics are the mainstay of treatment of most bacterial infections, despite the fact that some bacteria have developed resistance against them. However, the management of viral infections is far more challenging due to the nature of viral pathogenesis. Viruses are infective particles that can proliferate only in living cells and cannot replicate on their own. Furthermore, each virus has an affinity to a specific host cell and can multiply only within those cells. The human urinary tract is home to many viruses in both healthy and diseased states, despite the traditional belief that urine is sterile in healthy individuals (Table 1). This review aims to investigate the viruses in the human urinary tract in the healthy population and in patients afflicted with urinary tract infections (UTIs) or other infectious diseases.

\section{VIRAL COMMUNITY IN THE URINARY TRACTS OF HEALTHY INDIVIDUALS}

Recent studies have challenged the traditional belief that urine is sterile in healthy individuals. These studies have used the 16S rRNA sequencing approach to suggest that the healthy human bladder, as represented by the urine, is home to a vast microbial community [1-3]. Just detecting bacterial or viral genetic fragments in urine cannot confirm whether the microorganism is present in the bladder. To address this point, a research group conducted urine culture studies that expanded the conditions of the culture environment to detect organisms that may escape detection through conventional clinical microbiology culture methods. Their results showed that many bacteria identified through 16s rRNA studies could indeed be cultured in the laboratory [4], thus supporting the presence of bacterial communities in the human urinary tract.

However, less is known about the existence of viral 
Table 1. Viruses found in the human urinary tract of healthy individuals and those with infections

\begin{tabular}{cl}
\hline \multicolumn{1}{c}{ Health status of individual } & \multicolumn{1}{c}{ Viruses found in urinary tracts } \\
\hline $\begin{array}{c}\text { Healthy (found by the Homologous Virus Diversity Index } \\
{[\mathrm{HVDI}] \text { metagenomics study) }}\end{array}$ & Herpes virus \\
& Polyomavirus \\
& Human papillomavirus \\
& Bacteriophage (lambda phage, Staphylococcus phage PH15, \\
& Escherichia coli phage phiV10, Enterococcus phage phiFL4A \\
Lower urinary tract infections & Human polyomavirus (BKV) \\
& Adenoviruses (AdV) \\
& Cytomegalovirus (CMV) \\
Contagious infections & Herpes simplex virus (HSV) type-1 and type-2 \\
& Zika virus \\
& Severe acute respiratory syndrome coronavirus (SARS-CoV) \\
& SARS-CoV-2 \\
& West Nile virus \\
\hline
\end{tabular}

Table 2. Characteristics of infectious viruses found in the human urinary tract

\begin{tabular}{|c|c|c|c|}
\hline Virus & Genome & Main route of transmission & Symptoms \\
\hline Zika virus & $\begin{array}{l}\text { Positive-sense, single-stranded RNA; } \\
\text { about } 10.8 \mathrm{~kb}\end{array}$ & Vector-borne (mosquitoes) & $\begin{array}{l}\text { Fever, rash, arthritis or arthralgia, conjunctivitis, } \\
\text { myalgia, headache, retro-orbital pain, } \\
\text { neurologic complications }\end{array}$ \\
\hline West Nile virus & $\begin{array}{l}\text { Positive-sense, single-stranded RNA; } \\
\text { about } 10.8 \mathrm{~kb}\end{array}$ & Vector-borne (mosquitoes) & Fever, neuroinvasive disease \\
\hline SARS-CoV & $\begin{array}{l}\text { Positive-sense, single-stranded RNA; } \\
\text { about } 30 \mathrm{~kb}\end{array}$ & $\begin{array}{l}\text { Respiratory droplets, aerosolization, and } \\
\text { fomites }\end{array}$ & $\begin{array}{l}\text { Fever, severe cough, dyspnea, wheezing, } \\
\text { chest pain }\end{array}$ \\
\hline SARS-CoV-2 & $\begin{array}{l}\text { Positive-sense, single-stranded RNA; } \\
\text { about } 30 \mathrm{~kb}\end{array}$ & $\begin{array}{l}\text { Respiratory droplets, contact with mucous } \\
\text { membranes in the eyes, mouth, or nose }\end{array}$ & Fatigue, fever, dry cough, myalgia, dyspnea \\
\hline
\end{tabular}

SARS-CoV: severe acute respiratory syndrome coronavirus.

communities in a healthy human urinary tract. Many human organs, with an already established microbiome, such as the oral cavity, gut, respiratory, and skin, are home to both bacteria and viruses. An investigation that combined an epifluorescence microscopy study with a metagenomic approach searched for viral communities in urine and found potential evidence of the presence of several viruses including herpes virus, human papillomavirus, polyomavirus, and bacteriophage in patients without UTIs [5]. These patients were considered UTI negative when assessed through conventional methods. However, due to the presence of symptoms such as sepsis, pain during urination, pain in the prostate area, abdominal pain, or vaginal bleeding, further studies could reveal the role of viral communities as infectious agents in the urinary tract of these individuals.

\section{VIRAL CAUSES OF UTIS}

Patients with UTIs are usually infected with bacteria. Viral UTIs are less common, but they still occur, affecting immunocompromised patients after organ transplantation and causing hemorrhagic cystitis, prostatitis, seminal vesiculitis, and urethritis. The most common viral pathogens known to cause UTIs are adenovirus, human polyomavirus (BK virus), cytomegalovirus, and herpes simplex virus type-1 and type-2 (Table 2) [6]. The common diagnostic method to detect viral UTIs is a real-time polymerase chain reaction (RT-PCR).

\section{INFECTIOUS VIRUSES FOUND IN URINE}

\section{Zika Virus}

The Zika virus is a positive-sense, single-stranded RNA virus, a member of Flaviviridae [7]. The Zika virus is commonly transmitted to humans from mosquitoes, most notably Ae. aegypti and Ae. albopictus, which are active during the daytime in tropical and subtropical regions around the world [8]. While some infected individuals may be asymptomatic [9], others may present with fever, rash, arthritis or arthralgia, conjunctivitis, myalgia, headache, or retro-orbital pain, or even neurologic complications such as the Guillain-Barre syndrome [8]. 
Although the Zika virus is better known for its vector-borne transmission, emerging evidence suggests a non-vectorial route of transmission through different human bodily fluids, including urine. The genomic RNA of the Zika virus was detected using RT-PCR, and quantified by real-time quantitative reverse transcription PCR. One patient's urine contained $2.53 \times 10^{5}$ Zika virus RNA copies per ml [9]. Furthermore, infectious Zika virus particles were isolated from patients' urine samples using Vero cell cultures [9,10]. It is known that the Zika virus has an effect on the glomerulus in animal models, and although the virus is continuously found in urine, there is no study on the effect of the virus on UTIs [11].

\section{West Nile Virus}

The West Nile virus, another member of Flaviviridae, is a positive-sense, single-stranded RNA virus [7] is the leading cause of mosquito-borne disease in North America. The majority of patients infected with the West Nile virus show no symptoms, but less than $1 \%$ of those who are infected present with fever or develop neuro-invasive disease [12]. The West Nile virus has been successfully isolated and infected in Vero E6 and BHK21 cells [13,14]. One of these studies demonstrated that the West Nile virus can be isolated in urine even if the virus goes undetected in the blood by nucleic acid amplification tests [14]. Therefore, the infections due to the West Nile virus are detected more through urine samples than through the serum but have not been reported to cause any injury or damage to the organs of the urinary tract system. In one study, acute urinary retention associated with the Nile viral infection has been reported [15].

\section{Severe Acute Respiratory Syndrome (SARS)- Coronavirus}

Known for its spiked proteins, the positive, singlestranded RNA SARS-coronavirus is suspected to have originated from an interspecies transmission and infected the first human in 2002 [16,17]. Among the human population, the main routes of transmission are droplet infection, aerosolization, and fomites. The virus seems to infect the epithelium cells of the lower respiratory tract most severely, leading to symptoms such as fever, severe cough, difficulty in breathing, wheezing, and chest pain [17].

One study demonstrated that the virus isolated from urine was capable of infecting fetal rhesus monkey kidney cells in the first 3 weeks of illness [18], while another study showed that the virus isolated from convalescent patients up to 4 weeks after the disease onset was still capable of infecting Vero E6 cells [19].

\section{SARS-Coronavirus-2}

In 2019, the rapid spread of the novel coronavirus (SARS-CoV-2) led to the coronavirus disease 2019 (COVID-19) pandemic. While SARS-CoV and SARS-CoV-2 share similarities, such as their genomic sequence and ability to enter host cells via human angiotensin-converting enzyme 2 (ACE2), the differences between the spike proteins of SARS-CoV-2 and SARS-CoV resulted in SARS-CoV-2 having 10-20 times higher affinity to bind to ACE2 in the lower respiratory tract. The primary symptoms of COVID-19 patients include fatigue, fever, dry cough, myalgia, and dyspnea. It is pointed out that the role of the urologist is important in the management of a SARS-CoV-2 infection in hospitalized patients due to sepsis as a result of UTIs [20]. The virus is mainly transmitted through respiratory droplets and contact with the mucous membranes in the eyes, mouth, or nose [21]. The cell-surface protein ACE2, which is distributed to the lung and other organs, including the kidney, is found in $2.4 \%$ of urothelial cells, which are the main receptors for SARS-CoV-2 spike protein. Therefore, it is possible that the urothelial cells may be infected through the capillaries and urine [22].

In a case study involving a single COVID-19 patient, an RT-PCR conducted on the patient's urine samples, was followed by a successful infection of Vero cells using the SARS-CoV-2 obtained from the patient [23]. Moreover, postmortem findings of COVID-19 patients using electron microscopy found that SARS-CoV-2 had infected the renal tubular epithelium [24,25] and the podocytes [25]. Considering the isolation of infectious SARS-CoV-2 from urine together with electron microscopy, and studies suggesting direct renal infection, the transmission of SARS-CoV-2 through contact with infected urine is a growing concern.

\section{CONCLUSIONS}

The presence of a microbiome in the human urinary tract is a relatively recent finding. With further investigations and 
a better understanding of the bacterial as well as the viral community in the urinary tract through urinalysis, physicians may be able to treat UTIs more effectively and avoid any overtreatment. Furthermore, as more infectious diseases emerge, understanding the contagiousness of these viruses found in urine will be crucial in protecting both the public and healthcare providers' well-being. Research should continue to investigate whether the viruses found in the urine result in infections of the urinary tract or are present transiently as temporary microbiomes other site infections.

\section{CONFLICT OF INTEREST}

No potential conflict of interest relevant to this article was reported.

\section{AUTHOR CONTRIBUTIONS}

S.P. participated in data collection and wrote the manuscript. E.T.K. and J.S.H. participated in the review design and coordinatation and helped to draft the manuscription. All authors read and approved final manuscript.

\section{ORCID}

Sunho Park, https://orcid.org/0000-0001-8158-6506

Eui Tae Kim, https://orcid.org/0000-0002-1631-3197

Jung-Sik Huh, https://orcid.org/0000-0003-2767-4390

\section{REFERENCES}

1. Brubaker L, Nager CW, Richter HE, Visco A, Nygaard I, Barber $M D$, et al. Urinary bacteria in adult women with urgency urinary incontinence. Int Urogynecol J 2014;25:1179-84.

2. Nelson DE, Dong Q, Van der Pol B, Toh E, Fan B, Katz BP, et al. Bacterial communities of the coronal sulcus and distal urethra of adolescent males. PLoS One 2012;7:e36298.

3. Siddiqui H, Nederbragt AJ, Lagesen K, Jeansson SL, Jakobsen $\mathrm{KS}$. Assessing diversity of the female urine microbiota by high throughput sequencing of $16 \mathrm{~S}$ rDNA amplicons. BMC Microbiol 2011;11:244.

4. Hilt EE, McKinley K, Pearce MM, Rosenfeld AB, Zilliox MJ, Mueller ER, et al. Urine is not sterile: use of enhanced urine culture techniques to detect resident bacterial flora in the adult female bladder. J Clin Microbiol 2014;52:871-6.

5. Santiago-Rodriguez TM, Ly M, Bonilla N, Pride DT. The human urine virome in association with urinary tract infections. Front
Microbiol 2015;6:14.

6. Paduch DA. Viral lower urinary tract infections. Curr Urol Rep 2007;8:324-35.

7. Mukhopadhyay S, Kuhn RJ, Rossmann MG. A structural perspective of the flavivirus life cycle. Nat Rev Microbiol 2005;3:13-22.

8. Petersen LR, Jamieson DJ, Powers AM, Honein MA. Zika Virus. N Engl J Med 2016;374:1552-63.

9. Bonaldo MC, Ribeiro IP, Lima NS, Dos Santos AA, Menezes LS, da Cruz SO, et al. Isolation of infective Zika virus from urine and saliva of patients in Brazil. PLoS Negl Trop Dis 2016;10: e0004816.

10. Zhang FC, Li XF, Deng YQ, Tong YG, Qin CF. Excretion of infectious Zika virus in urine. Lancet Infect Dis 2016;16:641-2.

11. Alcendor DJ. Zika virus infection and implications for kidney disease. J Mol Med (Berl) 2018;96:1145-51.

12. Petersen LR, Brault AC, Nasci RS. West Nile virus: review of the literature. JAMA 2013;310:308-15.

13. Barzon L, Pacenti M, Franchin E, Squarzon L, Sinigaglia A, Ulbert $S$, et al. Isolation of West Nile virus from urine samples of patients with acute infection. J Clin Microbiol 2014;52:3411-3.

14. Barzon L, Pacenti M, Franchin E, Pagni S, Martello T, Cattai M, et al. Excretion of West Nile virus in urine during acute infection. J Infect Dis 2013;208:1086-92.

15. Shpall Al, Varpetian A, Ginsberg DA. Urinary retention in a patient with West Nile virus. Urology 2003;61:1259.

16. Stadler K, Masignani V, Eickmann M, Becker S, Abrignani S, Klenk HD, et al. SARS--beginning to understand a new virus. Nat Rev Microbiol 2003;1:209-18.

17. Peiris JS, Guan Y, Yuen KY. Severe acute respiratory syndrome. Nat Med 2004;10(12 Suppl):S88-97.

18. Chan KH, Poon LL, Cheng VC, Guan Y, Hung IF, Kong J, et al. Detection of SARS coronavirus in patients with suspected SARS. Emerg Infect Dis 2004;10:294-9.

19. Xu D, Zhang Z, Jin L, Chu F, Mao Y, Wang H, et al. Persistent shedding of viable SARS-CoV in urine and stool of SARS patients during the convalescent phase. Eur J Clin Microbiol Infect Dis 2005;24:165-71.

20. Mumm JN, Osterman A, Ruzicka M, Stihl C, Vilsmaier T, Munker D, et al. Urinary frequency as a possibly overlooked symptom in COVID-19 patients: does SARS-CoV-2 cause viral cystitis? Eur Urol 2020;78:624-8.

21. Li H, Liu SM, Yu XH, Tang SL, Tang CK. Coronavirus disease 2019 (COVID-19): current status and future perspectives. Int J Antimicrob Agents 2020;55:105951.

22. Zou X, Chen K, Zou J, Han P, Hao J, Han Z. Single-cell RNA-seq data analysis on the receptor ACE2 expression reveals the potential risk of different human organs vulnerable to 2019-nCoV infection. Front Med 2020;14:185-92.

23. Sun J, Zhu A, Li H, Zheng K, Zhuang Z, Chen Z, et al. Isolation of infectious SARS-CoV-2 from urine of a COVID-19 patient. Emerg Microbes Infect 2020;9:991-3. 
24. Farkash EA, Wilson AM, Jentzen JM. Ultrastructural evidence for direct renal infection with SARS-CoV-2. J Am Soc Nephrol 2020;31:1683-7.
25. Su H, Yang M, Wan C, Yi LX, Tang F, Zhu HY, et al. Renal histopathological analysis of 26 postmortem findings of patients with COVID-19 in China. Kidney Int 2020;98:219-27. 